Article

\title{
Exogenous of Indole-3-Acetic Acid Application Alleviates Copper Toxicity in Spinach Seedlings by Enhancing Antioxidant Systems and Nitrogen Metabolism
}

\author{
Qin Gong ${ }^{1,2}$, Zhaohua $\mathrm{Li}^{1,3, *}$, Ling Wang ${ }^{1}$, Tongwei Dai ${ }^{1}$, Qun Kang ${ }^{1}$ and Duandan Niu ${ }^{1}$ \\ 1 Faculty of Resources and Environmental Science, Hubei University, Wuhan 430062, China; \\ 201701110700051@stu.hubu.edu.cn (Q.G.); wlk87@outlook.com (L.W.); \\ 201711110811086@stu.hubu.edu.cn (T.D.); Kangqun@hubu.edu.cn (Q.K.); \\ 201811110811197@stu.hubu.edu.cn (D.N.) \\ 2 Further Education Colleges, Xinjiang Vocation College of Agriculture, Changji 831100, China \\ 3 Hubei Rural Safe Drinking Water Engineering Technology Research Center, Wuhan 430062, China \\ * Correspondence: zli@hubu.edu.cn
}

Received: 22 November 2019; Accepted: 13 December 2019; Published: 24 December 2019

\begin{abstract}
Indole-3-acetic acid (IAA) is a potential mediator in the protection of plants from copper $(\mathrm{Cu})$ toxicity and the enhancement of $\mathrm{Cu}$ tolerance. In this paper, spinach (Spinacia oleracea $\mathrm{L}$.) seedlings were cultivated in soil containing $700 \mathrm{mg} \mathrm{kg}^{-1} \mathrm{Cu}$ and the leaves of seedlings were sprayed with different concentrations of IAA. Exogenous IAA treatment reduced the malondialdehyde (MDA) concentrations in $\mathrm{Cu}$-stressed seedlings and increased biomass, proline content, and the activities of antioxidant enzymes. Exogenous IAA treatment also increased the levels of nitrogen $(\mathrm{N})$ assimilation compounds and the activities of $\mathrm{N}$-metabolizing enzymes, but reduced $\mathrm{NH}_{4}{ }^{+}$content. Notably, lower concentrations of IAA (10-40 $\left.\mathrm{mg} \mathrm{L}^{-1}\right)$ increased the $\mathrm{Cu}$ concentrations in roots and reduced the $\mathrm{Cu}$ concentrations in leaves, while higher concentrations of IAA $\left(50 \mathrm{mg} \mathrm{L}^{-1}\right)$ reduced the $\mathrm{Cu}$ concentrations in both roots and leaves to the lowest levels. The findings indicated that the application of IAA reduced $\mathrm{Cu}$ accumulation, alleviated $\mathrm{Cu}$ toxicity, and enhanced $\mathrm{Cu}$ tolerance in spinach seedlings. IAA application could be used as an alternative strategy for reducing $\mathrm{Cu}$ accumulation in vegetable crops and for remediating Cu-contaminated soil, in turn reducing the hazardous effects of heavy metal contamination on human health and the environment.
\end{abstract}

Keywords: indole-3-acetic acid; copper stress; antioxidant enzyme activity; nitrogen metabolism; spinach seedlings

\section{Introduction}

The contamination of soil with heavy metals is a global problem. In China, 100 million ha of land have been affected by heavy metal pollution [1] Notably, although copper $(\mathrm{Cu})$ is essential for plant growth and development, the element is also highly phytotoxic at high concentrations, since the free form of $\mathrm{Cu}$ is very active in the presence of mercaptan and oxygen, which would promote oxidative stress [2,3]. In recent years, the $\mathrm{Cu}$ contents in soil have dramatically increased due to anthropogenic activities, such as $\mathrm{Cu}$ mining, smelting waste discharge, the overapplication of $\mathrm{Cu}$-containing pesticides, and the arbitrary discharge of domestic sewage [4,5]. Such excessive levels of $\mathrm{Cu}$ contamination pose potential threats to the environment and human health, owing to the element's high toxicity, rapid accumulation in plant tissues, resistance to degradation, and ability to enter the human body through the consumption of contaminated foods [4]. 
In plants, excessive $\mathrm{Cu}$ levels can facilitate the formation of reactive oxygen species (ROS), which can cause cell oxidative damage and affect a wide range of biochemical and physiological processes, such as antioxidant activity, photosynthesis, mineral uptake, membrane integrity, and nitrogen $(\mathrm{N})$ and protein metabolism [6]. Therefore, numerous studies have explored mechanisms of counteracting the adverse effects of $\mathrm{Cu}$-stress and to improve $\mathrm{Cu}$ tolerance of plants via exogenous application of phytohormones [7]. Indole-3-acetic acid (IAA), which is an important signaling molecule in higher plants, functions not only as a plant growth regulator but also as an essential stress tolerance substance [8]. In addition, it alleviates Cu-stress damage [9]. For example, the application of $50 \mu \mathrm{mol} \mathrm{L}{ }^{-1}$ IAA could alleviate the harmful effects of $\mathrm{Cu}$ toxicity and increase $\mathrm{Cu}$ resistance in wheat plants, while Ouzounidou and Ilias [10] reported that the application of $100 \mu \mathrm{mol} \mathrm{L}^{-1}$ IAA minimized the toxic effects of $\mathrm{Cu}$ in the roots of sunflower (Helianthus annuus L.), in turn promoting root growth and root hair formation.

The exogenous application of IAA has also been reported to alleviate the adverse effects of heavy metal stress on $\mathrm{N}$ metabolism [11]. $\mathrm{N}$ is the principal component of all amino acids, proteins, and some nitrogenous compounds that protect plants from abiotic stress [12]. Inorganic forms of $\mathrm{N}$, such as nitrate $\left(\mathrm{NO}_{3}{ }^{-}\right)$, are readily taken up by plants, converted into ammonium $\left(\mathrm{NH}_{4}{ }^{+}\right)$, and eventually integrated into amino acids and proteins [13], and such processes involve several enzymes, including nitrate reductase (NR), nitrite reductase (NiR), glutamine synthetase (GS), glutamine 2-oxoglutarate aminotransferase (GOGAT), and glutamate dehydrogenase (GDH) [12]. Gangwar and Singh [11] reported that the application of $10 \mu \mathrm{mol} \mathrm{L}^{-1}$ IAA increased the GS, GOGAT, and GDH activities, in addition to $\mathrm{N}$ metabolism of $\mathrm{Cd}$-stressed pea seedlings. However, little information is available regarding the influence of IAA on $\mathrm{N}$ metabolism under $\mathrm{Cu}$ stress.

Spinach (Spinacia oleracea L.), which is an important crop rich in vitamins, organic acids, carotenoids, alkaline minerals, and antioxidants [14,15], has been reported to exhibit strong $\mathrm{Cu}$ tolerance, owing to its large leaf surface area, relatively high growth rate, and high heavy metal absorption rate [16-18]. However, basic research on the biochemical and physiological responses of spinach to $\mathrm{Cu}$ is scarce, not to mention the potential role of IAA in spinach seedlings grown under high $\mathrm{Cu}$ stress. Therefore, the present study investigated the protective effect of IAA on $\mathrm{Cu}$ stress in spinach seedlings. The aim of the present study was to investigate whether the exogenous application of IAA can relieve $\mathrm{Cu}$ stress and damage, and enhance $\mathrm{Cu}$ tolerance via alteration of the uptake of $\mathrm{Cu}$, change in antioxidant system, and shifts in $\mathrm{N}$ metabolism.

\section{Materials and Methods}

\subsection{Plant Materials}

The experiments were conducted in October 2018 in a solar greenhouse at the Faculty of Resources and Environmental Science at Hubei University, China. The test variety was Japanese big-leaf spinach, which was obtained from the seed breeding station of Wangzhendian, Qingxian County, Hebei Province, China. Healthy seeds were surface-sterilized by soaking in $0.1 \% \mathrm{NaClO}$ for $10 \mathrm{~min}$, washed extensively in deionized water, evenly spaced in Petri dishes (9-cm diameter) that contained filter paper, and then incubated at $25^{\circ} \mathrm{C}$ in darkness. After $48 \mathrm{~h}$, germinated seeds were selected and planted in peat soil. After reaching $10 \mathrm{~cm}$ in height, uniform healthy seedlings were transplanted into pots and irrigated with complete Hoagland nutrient solution. Each pot contained 10 seedlings, and each pot contained $3 \mathrm{~kg}(2.1 \mathrm{~kg}$ DW) of a $(7: 3, v / v)$ mixture of peat and perlite. The plants were allowed to acclimate for $20 \mathrm{~d}$ before the experimental treatments were applied.

\subsection{Test Treatment}

The potted plants were divided into eight groups. One group in which only the Hoagland nutrient solution was added, including $4.56 \mathrm{mg} \mathrm{kg}^{-1} \mathrm{Cu}$, was used as the control (C1), and the other seven groups were irrigated with Hoagland nutrient solution containing $700 \mathrm{mg} \mathrm{kg}^{-1} \mathrm{Cu}$. The total amount 
of irrigated solution in each pot in the eight groups was $400 \mathrm{~mL}$. The Hoagland nutrient solution was adjusted to a $\mathrm{pH}$ of $6.5 \pm 0.3$ using $0.1 \mathrm{mmol} \mathrm{L}^{-1} \mathrm{NaOH}$ or $\mathrm{HCl}$. Cu was supplied as $\mathrm{CuSO}_{4}$ (analytical reagent).

Subsequently, the leaves of the other seven groups were sprayed with different concentrations of IAA $\left(0,10,20,30,40,50\right.$, and $\left.60 \mathrm{mg} \mathrm{L}^{-1}\right)$ and the treatments were designated as $\mathrm{C} 2, \mathrm{~T} 1, \mathrm{~T} 2, \mathrm{~T} 3, \mathrm{~T} 4, \mathrm{~T} 5$, and T6, respectively. The IAA solution was mixed with Tween- $20\left(\mathrm{C}_{58} \mathrm{H}_{114} \mathrm{O}_{26}\right.$, leaf surfactant), and the total amount of IAA in each pot was $20 \mathrm{~mL}$. The $\mathrm{C} 2$ plants were sprayed with an equal amount of water ( $20 \mathrm{~mL} /$ pot) mixed with Tween-20. Each treatment has three replicates in a randomized block design.

Evaporative water loss was compensated for by adding deionized water until reaching a weight of $3.4 \pm 0.05 \mathrm{~kg}$, and the seedlings were cultivated under a $14 \mathrm{~h}$ photoperiod (light intensity of $8000 \mathrm{Lux}$ ), with a relative humidity of $70-80 \%$ and a day/night temperature of $22 / 15^{\circ} \mathrm{C}$. After $7 \mathrm{~d}$ of treatment, plants were collected for the measurement of indicators.

\subsection{Measurement Indicators and Methods}

\subsubsection{Determination of Biomass}

The seedlings were carefully removed from the pots, rinsed using tap water, and then rinsed thrice using deionized water. After drying with blotting paper, the fresh weight (FW) of leaves, stems, and roots were measured immediately, and dry weight (DW) was measured after the samples were fixed in an oven at $105^{\circ} \mathrm{C}$ for $10 \mathrm{~min}$, and then dried to a constant weight at $80^{\circ} \mathrm{C}$.

\subsection{2. $\mathrm{Cu}$ Content Measurements}

After separating the leaves and roots of the seedlings, the roots were soaked in $20 \mathrm{mmol} \mathrm{L}^{-1}$ $\mathrm{Na}_{2}$-EDTA for $3 \mathrm{~h}$ to remove surface-adsorbed $\mathrm{Cu}$ and then washed repeatedly using deionized water. The root and leaf samples were oven-dried $\left(105^{\circ} \mathrm{C}\right.$ for $20 \mathrm{~min}$ and $80{ }^{\circ} \mathrm{C}$ for $72 \mathrm{~h}$ ), ground, and then digested using a 4:1 (v:v) mixture of $\mathrm{HNO}_{3}$ and $\mathrm{HClO}_{4}$. Finally, the $\mathrm{Cu}$ concentrations were determined using inductively coupled plasma atomic emission spectroscopy (ICP-AES; Fisons ARL Accuris, Ecublens, Switzerland) [19].

\subsubsection{Biochemical Indicators Measurements}

Malondialdehyde (MDA) was measured using the thiobarbituric acid method [20], whereas proline content was determined by acidic ninhydrin colorimetry [20]. Superoxide dismutase (SOD, EC 1.15.1.1), peroxidase (POD, EC 1.11.1.7), and ascorbate peroxidase (APX, EC 1.11.1.11) activity were assayed according to the methods described by Beauchamp and Fridovich [21], Batish [22], Nakano, and Asada [23], respectively. The detailed methods of all the biochemical methods are described in our previous study [17]. Lastly, the glutathione reductase (GR, EC 1.6.4.2) activity was measured by monitoring the glutathione dependent oxidation of NADPH. The reaction mixture contained $0.1 \mathrm{~mL}$ extract solution, $0.1 \mathrm{~mL} 2.4 \mathrm{mmol} \mathrm{L}^{-1} \mathrm{NADPH}, 1.7 \mathrm{~mL}$ of HEPES, and $0.1 \mathrm{~mL}$ of $10 \mathrm{mmol} \mathrm{L}^{-1} \mathrm{GSSG}$, and the absorbance of the mixtures was monitored at $340 \mathrm{~nm}$ [24].

\subsubsection{Leaf $\mathrm{N}, \mathrm{NO}_{3}{ }^{-}$and $\mathrm{NH}_{4}{ }^{+}$Contents Measurement}

Total $\mathrm{N}$ was quantified using the micro-Kjeldahl method [25] while the $\mathrm{NO}_{3}{ }^{-}$and $\mathrm{NH}_{4}{ }^{+}$ concentrations were determined using an enzyme-linked immunoassay (ELISA) kit (Shanghai Best Choice Biotechnology Co., Ltd., Shanghai, China).

\subsubsection{Amino Acids and Protein Concentration Measurements}

To measure amino acid concentrations, fresh leaves $(0.5 \mathrm{~g})$ were homogenized in $5 \mathrm{~mL}$ of $10 \%$ acetic acid, diluted to $100 \mathrm{~mL}$ with redistilled water, and then filtered. Filtered homogenate solution $(1 \mathrm{~mL})$ was then mixed with $3 \mathrm{~mL}$ of ninhydrin solution, $1 \mathrm{~mL}$ of ammonia-free distilled water, and $0.1 \mathrm{~mL}$ of ascorbic acid in a test tube. The mixed solution was heated in a water bath at $100{ }^{\circ} \mathrm{C}$ for 15 
min. After cooling, the solution was diluted to $20 \mathrm{~mL}$ with $60 \%$ ethanol, and the absorbance of the solution was measured at $570 \mathrm{~nm}$ [26].

Soluble protein was measured according to the method of Bradford [27]. Frozen leaves ( $0.5 \mathrm{~g})$ were homogenized in $5 \mathrm{~mL}$ of $0.1 \mathrm{~mol} \mathrm{~L}^{-1}$ phosphate buffer solution ( $\mathrm{pH}$ 7.0) and centrifuged at 4000 and $4{ }^{\circ} \mathrm{C}$ for $10 \mathrm{~min}$. Sample extract $(0.1 \mathrm{~mL})$ was mixed with $5 \mathrm{~mL}$ of Coomassie brilliant blue solution ( $0.1 \mathrm{~g}$ Coomassie brilliant blue [G-250] in $50 \mathrm{~mL}$ of $90 \%$ ethanol and $85 \%$ phosphoric acid) and the absorbance values recorded at $595 \mathrm{~nm}$. Protein concentration was determined by comparing the absorbance values to the values of a standard curve established using bovine serum albumin.

\subsubsection{N Metabolizing Enzymes Activity Measurement}

The activities of N-metabolizing enzymes (NR, NiR, GS, GOGAT, and GDH) were measured using commercially available chemical kits (Shanghai Best Choice Biotechnology) according to the manufacturer's instructions. Leaf samples $(0.1 \mathrm{~g})$ were crushed in a chilled mortar and pestle and extracted in $1 \mathrm{~mL}$ buffer (provided by each corresponding kit) in a 2-mL centrifuge tube. The sample was centrifuged and the supernatant was stored in a new tube. The reaction tube contained the recommended reagents for each test kit and conditions were maintained strictly according to the provided instructions. The absorption readings for the five enzymes were recorded at $450 \mathrm{~nm}$ using a spectrophotometer.

\subsection{Statistical Analysis}

Data were reported as mean \pm standard deviation (SD) values of three replicate experiments and were analyzed using SPSS Statistics 17.0 (SPSS Inc., Chicago, IL, USA). One-way analysis of variance and Duncan's multiple range tests were used to determine the significance of differences among the treatment groups, with a significance level of 0.05 . The figures were illustrated using Origin Pro 9.0 (OriginLab Co., Northampton, MA, USA).

\section{Results}

\subsection{Effect of IAA Treatment on Total Biomass Accumulation}

The total FW and DW of the C2 treatment were $31.94 \%$ and $40.93 \%$ higher, respectively, than those of the treatment $\mathrm{C} 1(p<0.05$ Figure 1), and both measures (total FW and DW) increased with an increase in IAA concentrations (T1-T6). Total FW and DW were the greatest in the treatment T6 and were $49.17 \%$ and $69.99 \%$ greater than in the C2 treatment, respectively. Similar trends were also observed for the biomass of leaves, stems, and roots.
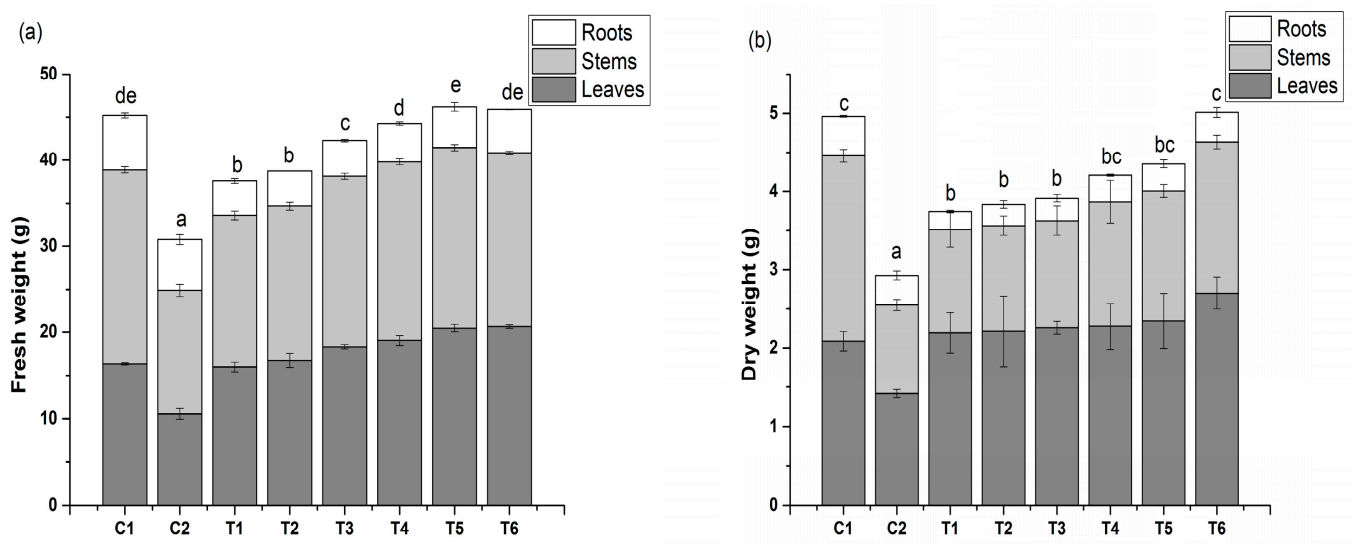

Figure 1. Effects of indole-3-acetic acid (IAA) on the fresh weight (a) and dry weight (b) of spinach seedlings under $\mathrm{Cu}$ stress. Values and error bars indicate means \pm standard deviation $(n=3)$. Different letters indicate a significant difference between treatments at $p<0.05$ according to Duncan's multiple-comparisons test. 


\subsection{Effect of IAA Treatment on Cu Accumulation in the Leaves and Roots}

The $\mathrm{Cu}$ concentrations of the $\mathrm{C} 2$ leaves and roots were 144.79 and 23.36 times greater than those of the $\mathrm{C} 1$ leaves and roots, respectively (Table 1). Compared with the $\mathrm{C} 2$ treatment, the $\mathrm{Cu}$ accumulation of spinach leaves decreased gradually along the treatments T1-T6, with the T6 leaves accumulating 39.61 times less $\mathrm{Cu}$ than the $\mathrm{C} 2$ leaves. However, a different trend was observed for the $\mathrm{Cu}$ concentrations in roots. Instead of decreasing continuously, the $\mathrm{Cu}$ concentrations in the $\mathrm{T} 1, \mathrm{~T} 2$, $\mathrm{T} 3$, and $\mathrm{T} 4$ roots increased by $0.20,2.10,2.17$, and 1.92 times, respectively, and then that of T5 and T6 decreased by 0.29 and 0.87 times, respectively.

Table 1. Effects of IAA on the Cu Accumulation by Cu-Stressed Spinach Seedlings.

\begin{tabular}{ccc}
\hline Treatment & Leaf Concentration & Root Concentration \\
\hline & $\left(\boldsymbol{\mu} \mathbf{g ~ g}^{-\mathbf{1}}\right)$ & $\left(\boldsymbol{\mu} \mathbf{g ~ g}^{\mathbf{- 1}}\right)$ \\
\hline C1 & $19.72 \pm 0.14 \mathrm{a}$ & $7.97 \pm 0.06 \mathrm{a}$ \\
C2 & $2875.00 \pm 2.16 \mathrm{~h}$ & $194.15 \pm 1.06 \mathrm{~d}$ \\
T1 & $1777.83 \pm 15.46 \mathrm{~g}$ & $232.02 \pm 0.78 \mathrm{e}$ \\
T2 & $1616.50 \pm 13.08 \mathrm{f}$ & $601.50 \pm 8.98 \mathrm{~g}$ \\
T3 & $1475.50 \pm 16.57 \mathrm{e}$ & $616.17 \pm 2.49 \mathrm{~h}$ \\
T4 & $1319.17 \pm 1.25 \mathrm{~d}$ & $566.33 \pm 9.80 \mathrm{f}$ \\
T5 & $122.03 \pm 2.62 \mathrm{c}$ & $137.55 \pm 4.71 \mathrm{c}$ \\
T6 & $72.58 \pm 5.03 \mathrm{~b}$ & $25.87 \pm 0.06 \mathrm{~b}$ \\
\hline
\end{tabular}

Data are mean \pm standard error of three replicates. Values within a row followed by the same letter are not significantly different $(p<0.05)$ based on Duncan's multiple-comparisons test.

\subsection{Effect of IAA Treatment on MDA and Proline Concentrations}

The MDA concentrations of the $\mathrm{C} 2$ treatment was markedly greater than that of the $\mathrm{C} 1$ treatment (Figure 2). However, the MDA concentration decreased gradually with an increase in IAA concentrations (T1-T6), with the T5 and T6 treatments yielding $42.58 \%$ and $43.85 \%$ less MDA, respectively, than the treatment $\mathrm{C} 2$. In contrast, the proline contents increased with an increase in IAA concentrations (T1-T6), with the $\mathrm{T} 6$ treatment yielding $62.2 \%$ more proline than the $\mathrm{C} 2$ treatment.
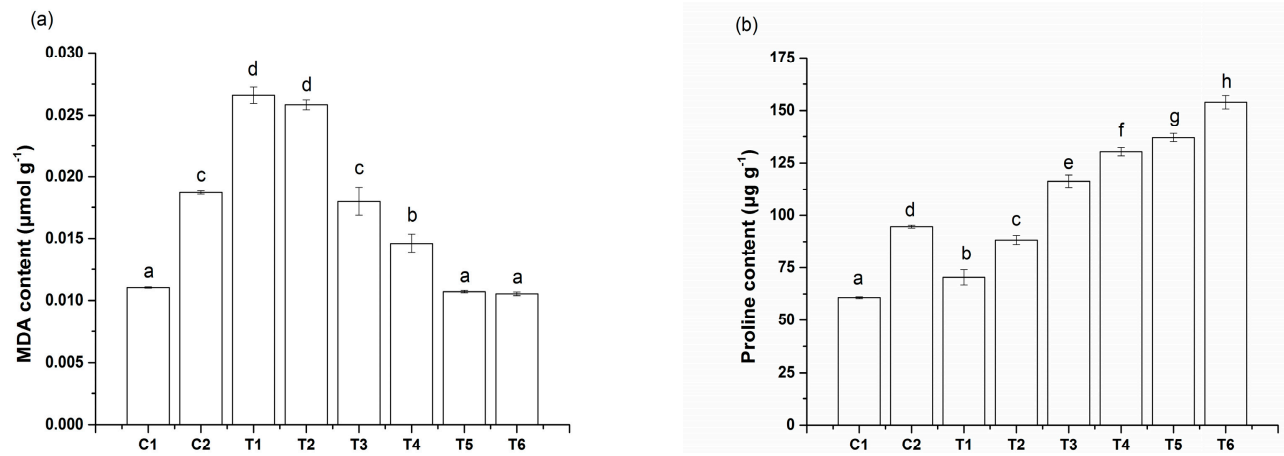

Figure 2. Effects of IAA on malondialdehyde (MDA) (a) and proline (b) contents of spinach seedlings under $\mathrm{Cu}$ stress. Values and error bars indicate means \pm standard deviation $(n=3)$. Different letters indicate a significant difference between treatments at $p<0.05$ according to Duncan's multiple-comparisons test.

\subsection{Effect of IAA Treatment on Antioxidant Enzyme Activities}

As shown in Figure 3, the SOD, POD, and APX activities (Figure 3) of the C2 treatment were greater $(46.70 \%, 57.07 \%$, and $99.97 \%$, respectively) than those of the $\mathrm{C} 1$ treatment $(p<0.05)$, while the GR activity of $\mathrm{C} 2$ treatment was $45.91 \%$ lower than that of the $\mathrm{C} 1$ treatment. Furthermore, the SOD activities of the T1-T6 treatments were consistently higher than those of the $\mathrm{C} 2$ treatment, with the T6 
treatments exhibiting $44.05 \%$ more SOD activity than the $\mathrm{C} 2$ treatment. In addition, the POD activities of T1-T6 treatments were lower than those of the $\mathrm{C} 2$ treatment, even though the differences were generally insignificant, and the APX activities of the T1-T5 treatments were lower than those of the C2 treatment, while the APX activities of the T6 treatment were remarkably greater (55.56\%). Finally, the GR activities remained consistently low (T1-T3), until they increased at higher IAA concentrations (T4-T6).

(a)

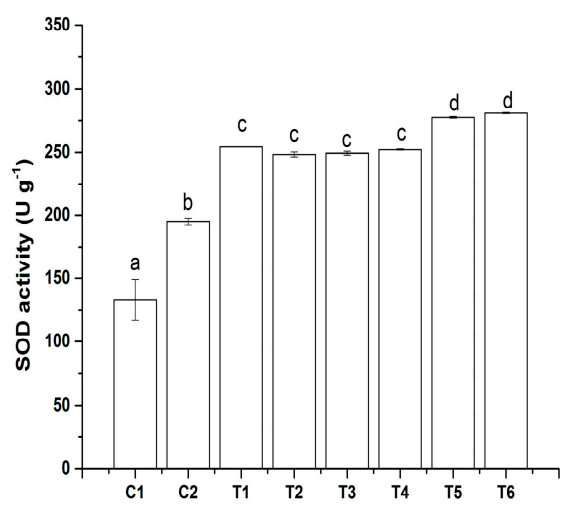

(c)

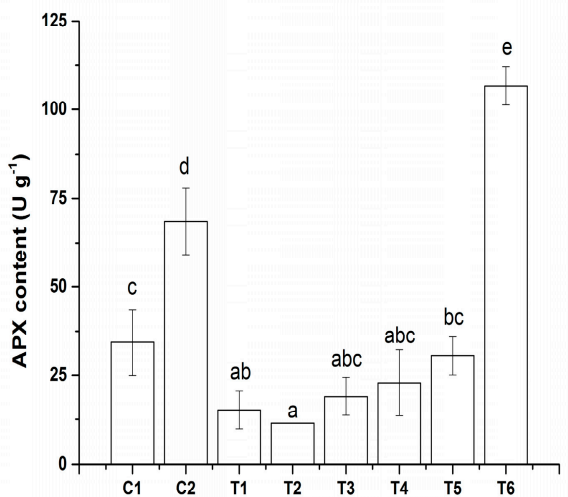

(b)

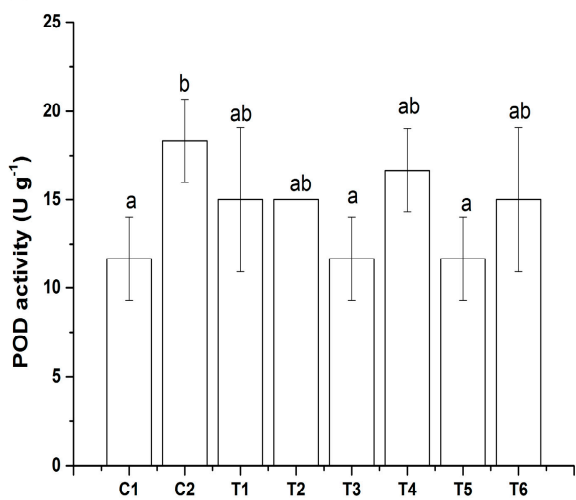

(d)

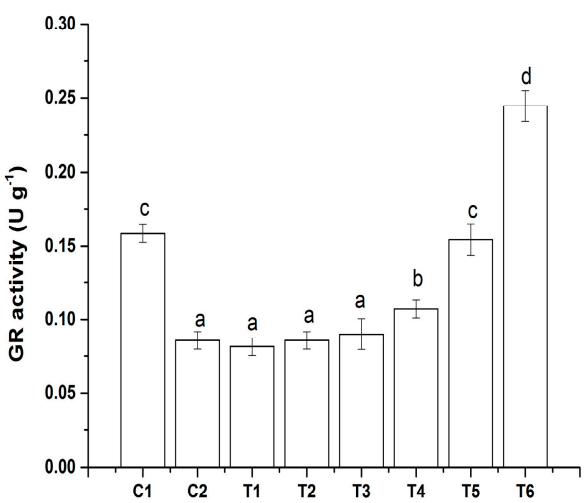

Figure 3. Effects of IAA on superoxide dismutase (SOD; $\mathbf{a}$ ), Peroxidase (POD; $\mathbf{b}$ ), Ascorbate peroxidase $(A P X ; \mathbf{c})$ and glutathione reductase (GR; $\mathbf{d})$ activities of spinach seedlings under $\mathrm{Cu}$ stress. Values and error bars indicate means \pm standard deviation $(n=3)$. Different letters indicate a significant difference between treatments at $p<0.05$ according to Duncan's multiple-comparisons test.

\subsection{Effect of IAA Treatment on Total N Content and N Assimilation Compounds}

The total $\mathrm{N}, \mathrm{NO}_{3}{ }^{-}$, free amino acid, and soluble protein contents (Table 2) of the $\mathrm{C} 2$ treatment were $3.24 \%, 43.55 \%, 48.68 \%$, and $36.08 \%$ lower, respectively, than those of the $\mathrm{C} 1$ treatment, whereas the $\mathrm{NH}_{4}{ }^{+}$content was 1.43 times greater. Apparently, when IAA was applied to $\mathrm{Cu}$-stressed seedlings (T1-T6), total $\mathrm{N}$ concentration decreased in the T1-T4 treatments, and were significantly lower than in the $\mathrm{C} 2$ treatment $(p<0.05)$, while total $\mathrm{N}$ contents in the T5-T6 treatments were not significantly different $(p>0.05)$, from the total $\mathrm{N}$ concentrations in the $\mathrm{C} 2$ treatment. In addition, the concentrations of $\mathrm{NO}_{3}{ }^{-}$and soluble protein increased notably with an increase in IAA concentrations (T1-T6), with the $\mathrm{T} 6$ treatment accumulating 1.06 times the $\mathrm{NO}_{3}{ }^{-}$in the $\mathrm{C} 2$ treatment, while the soluble protein contents were not significantly different between the T6 treatment and the $\mathrm{C} 2$ treatment. The $\mathrm{NH}_{4}{ }^{+}$ concentrations decreased with an increase in IAA concentrations (T1-T6), with the T5 and T6 plants accumulating $47.06 \%$ and $41.18 \%$ less $\mathrm{NH}_{4}{ }^{+}$than the $\mathrm{C} 2$ treatment, respectively. Notably, the free amino acid contents of the IAA together with the $\mathrm{Cu}$-stressed seedlings (except for the T5 treatment) were higher than those of the $\mathrm{C} 2$ treatment. 
Table 2. Effects of IAA on total $\mathrm{N}$ content and $\mathrm{N}$ assimilation compounds under $\mathrm{Cu}$ stress.

\begin{tabular}{|c|c|c|c|c|c|}
\hline Treatment & $\begin{array}{l}\text { Total N } \\
\text { Content } \\
\left(\mathrm{g} \mathrm{kg}^{-1}\right)\end{array}$ & $\begin{array}{c}\mathrm{NO}_{3}{ }^{-} \text {Content } \\
\left(\mathrm{g} \mathrm{kg}^{-1}\right)\end{array}$ & $\begin{array}{c}\mathrm{NH}_{4}{ }^{+} \text {Content } \\
\quad\left(\mathrm{g} \mathrm{kg}^{-1}\right)\end{array}$ & $\begin{array}{c}\text { Free Amino } \\
\text { Acid Content } \\
\left(\mathrm{g} \mathrm{kg}^{-1}\right)\end{array}$ & $\begin{array}{c}\text { Soluble Protein } \\
\text { Content } \\
\left(\mathrm{g} \mathrm{kg}^{-1}\right)\end{array}$ \\
\hline $\mathrm{C} 1$ & $83.24 \pm 0.91 \mathrm{e}$ & $1.24 \pm 0.016 \mathrm{f}$ & $0.07 \pm 0.0018 \mathrm{a}$ & $0.76 \pm 0.010 \mathrm{f}$ & $18.82 \pm 0.60 \mathrm{~cd}$ \\
\hline C2 & $80.54 \pm 0.66$ cde & $0.70 \pm 0.039 a$ & $0.17 \pm 0.0001 \mathrm{~h}$ & $0.39 \pm 0.004 b$ & $12.03 \pm 0.14 \mathrm{a}$ \\
\hline $\mathrm{T} 1$ & $77.47 \pm 1.92 \mathrm{ab}$ & $0.75 \pm 0.006 b$ & $0.16 \pm 0.0002 \mathrm{~g}$ & $0.51 \pm 0.014 \mathrm{~d}$ & $14.83 \pm 1.18 b$ \\
\hline T2 & $78.06 \pm 1.64 \mathrm{abc}$ & $1.10 \pm 0.018 \mathrm{~d}$ & $0.12 \pm 0.0003 \mathrm{f}$ & $0.49 \pm 0.012 \mathrm{~d}$ & $13.72 \pm 1.18 \mathrm{ab}$ \\
\hline T3 & $76.02 \pm 1.48 \mathrm{a}$ & $1.01 \pm 0.0041 \mathrm{c}$ & $0.11 \pm 0.0004 \mathrm{~d}$ & $0.41 \pm 0.020 \mathrm{~b}$ & $13.74 \pm 0.70 \mathrm{ab}$ \\
\hline $\mathrm{T} 4$ & $78.91 \pm 1.58 \mathrm{bcd}$ & $1.19 \pm 0.0039 \mathrm{e}$ & $0.12 \pm 0.0006 \mathrm{e}$ & $0.67 \pm 0.016 \mathrm{e}$ & $14.88 \pm 1.28 b$ \\
\hline T5 & $81.14 \pm 0.35 \mathrm{de}$ & $1.23 \pm 0.0084 \mathrm{ef}$ & $0.09 \pm 0.0006 b$ & $0.30 \pm 0.011 \mathrm{a}$ & $17.70 \pm 0.05 c$ \\
\hline T6 & $81.24 \pm 0.34 \mathrm{de}$ & $1.44 \pm 0.039 \mathrm{~g}$ & $0.10 \pm 0.0005 c$ & $0.44 \pm 0.014 c$ & $20.51 \pm 0.77 \mathrm{~d}$ \\
\hline
\end{tabular}

$\mathrm{N}$, nitrogen; $\mathrm{NO}_{3}{ }^{-}$, nitrate nitrogen; $\mathrm{NH}_{4}{ }^{+}$, ammonium nitrogen. Data are mean \pm standard error of three replicates. Values within a row followed by the same letter are not significantly different $(p<0.05)$ by Duncan's multiple-comparisons test.

\subsection{Effect of IAA Treatment on N Metabolizing Enzyme Activities}

The NR, NiR, GS, and GOGAT activities of the C2 treatment were $57.78 \%, 30.64 \%, 22.92 \%$, and $12.36 \%$ lower, respectively, than those of the $\mathrm{C} 1$ treatment, whereas GDH activity was $38.64 \%$ higher (Table 3). More specifically, the NR activities of T1-T6 treatments exhibited an increasing trend at two stages (T2 and T6), with the greatest increase (1.02 times) observed in the T6 treatment, when compared to the $\mathrm{C} 2$ treatment. The NiR and GDH activities of the IAA-treated (except for the T1 treatment) were greater than those of the $\mathrm{C} 2$ treatment. However, the activities of both GS and GOGAT were decreased initially and subsequently increased in the T1-T6 treatments. Greater increases in GS and GOGAT activities were observed in the T4-T6 and the T3-T6 treatments, respectively.

Table 3. Effects of IAA on N Metabolizing Enzymes Activities under Copper Stress.

\begin{tabular}{|c|c|c|c|c|c|}
\hline Treatment & $\begin{array}{c}\mathrm{NR} \\
\left(\mathrm{U} \mathrm{g}^{-1}\right)\end{array}$ & $\begin{array}{c}\mathrm{NiR} \\
\left(\mathrm{U} \mathrm{g}^{-1}\right)\end{array}$ & $\begin{array}{c}\mathrm{GS} \\
\left(\mathrm{U} \mathrm{g}^{-1}\right)\end{array}$ & $\begin{array}{c}\text { GOGAT } \\
\left(\mathrm{Ug}^{-1}\right)\end{array}$ & $\begin{array}{c}\text { GDH } \\
\left(\mathrm{U} \mathrm{g}^{-1}\right)\end{array}$ \\
\hline $\mathrm{C} 1$ & $1224.75 \pm 18.71 \mathrm{e}$ & $2537.13 \pm 15.71 \mathrm{f}$ & $0.48 \pm 0.004 \mathrm{f}$ & $1.78 \pm 0.028 \mathrm{~d}$ & $0.044 \pm 0.0003 \mathrm{a}$ \\
\hline $\mathrm{C} 2$ & $517.03 \pm 14.06 \mathrm{a}$ & $1759.71 \pm 3.93 \mathrm{~b}$ & $0.37 \pm 0.003 c$ & $1.56 \pm 0.019 c$ & $0.061 \pm 0.0014 \mathrm{c}$ \\
\hline $\mathrm{T} 1$ & $659.59 \pm 8.25 b$ & $1582.01 \pm 61.21 \mathrm{a}$ & $0.23 \pm 0.006 a$ & $1.30 \pm 0.026 b$ & $0.051 \pm 0.0009 \mathrm{~b}$ \\
\hline $\mathrm{T} 2$ & $803.43 \pm 34.34 \mathrm{c}$ & $1848.56 \pm 37.87 \mathrm{c}$ & $0.29 \pm 0.006 b$ & $1.24 \pm 0.016 \mathrm{a}$ & $0.072 \pm 0.0010 \mathrm{~d}$ \\
\hline T3 & $658.32 \pm 10.95 b$ & $2128.98 \pm 21.86 \mathrm{~d}$ & $0.37 \pm 0.005 c$ & $1.81 \pm 0.016 \mathrm{~d}$ & $0.088 \pm 0.0003 \mathrm{f}$ \\
\hline $\mathrm{T} 4$ & $781.79 \pm 12.47 \mathrm{c}$ & $2495.48 \pm 48.25$ ef & $0.41 \pm 0.007 \mathrm{~d}$ & $2.09 \pm 0.013 \mathrm{~g}$ & $0.088 \pm 0.0013 \mathrm{f}$ \\
\hline $\mathrm{T} 5$ & $819.98 \pm 8.25 c$ & $2437.17 \pm 34.23 \mathrm{e}$ & $0.41 \pm 0.004 \mathrm{~d}$ & $1.99 \pm 0.006 \mathrm{f}$ & $0.079 \pm 0.0019 \mathrm{e}$ \\
\hline T6 & $1045.28 \pm 22.48 \mathrm{~d}$ & $2792.57 \pm 23.89 \mathrm{~g}$ & $0.42 \pm 0.003 \mathrm{e}$ & $1.92 \pm 0.005 \mathrm{e}$ & $0.072 \pm 0.0015 \mathrm{~d}$ \\
\hline
\end{tabular}

$\mathrm{NR}$, nitrate reductase; NiR, nitrite reductase; GS, glutamine synthetase; GOGAT, glutamine 2-oxoglutarate aminotransferase; GDH, glutamate dehydrogenase. Data are mean \pm standard error of three replicates. Values within a row followed by the same letter are not significantly different $(p<0.05)$ by Duncan's multiple-comparisons test.

\section{Discussion}

The present study was undertaken to identify the potential mechanisms and the influence of IAA in protecting spinach seedlings from $\mathrm{Cu}$ toxicity and improving $\mathrm{Cu}$ tolerance. Notably, exogenous addition of different concentrations of IAA not only enhanced $\mathrm{Cu}$ tolerance of spinach seedlings but also alleviated the damage of spinach seedlings due to $\mathrm{Cu}$ stress. The results demonstrated that low concentrations of IAA (10-40 $\mathrm{mg} \mathrm{L}^{-1}$ ) increased the $\mathrm{Cu}$ concentrations in $\mathrm{Cu}$-stressed seedling roots, but reduced the $\mathrm{Cu}$ concentrations of $\mathrm{Cu}$-stressed seedling leaves. The higher $\mathrm{Cu}$ levels in the roots of the IAA-treated plants could have occurred because (i) IAA stimulated lateral root formation, which supports more absorption of minerals [28]; (ii) roots act as a barrier against metal translocation to the upper parts of plants as a tolerance strategy [29]; and (iii) exogenous IAA may improve the redistribution of metals to aerial parts of plants, as a potential defensive mechanism against root damage [30]. In addition, the highest concentration of IAA $\left(60 \mathrm{mg} \mathrm{L}^{-1}\right)$, which yielded the most substantial reductions in $\mathrm{Cu}$ concentrations in the leaves and roots of $\mathrm{Cu}$-stressed seedlings, effectively 
mitigated the toxic effects of $\mathrm{Cu}$ on seedlings. Other studies have also reported that IAA treatment (10 $\left.\mu \mathrm{mol} \mathrm{L}^{-1}\right)$ can alleviate the Mn toxicity symptoms and promote the growth of pea seedlings [9]. In addition, soaking wheat grains in $50 \mu \mathrm{mol} \mathrm{L}^{-1}$ IAA reduced $\mathrm{Cu}$ accumulation and alleviated $\mathrm{Cu}$ toxicity under $\mathrm{Cu}$-stress conditions [8].

Recently, several investigators have reported that exogenously applied IAA at concentrations between 0.01 and $10 \mu \mathrm{mol} \mathrm{L}{ }^{-1}$ can promote growth as well as alleviate toxic effects of abiotic stress in different plant species $[28,31,32]$, while higher IAA concentrations inhibit growth and cause oxidative damage in plants [33]. In contrast, in the present study, even at higher IAA concentrations, the biomass of $\mathrm{Cu}$-treated seedlings continued to increase with an increase in IAA concentrations, and was the greatest at the highest tested concentration $\left(60 \mathrm{mg} \mathrm{L}^{-1} \mathrm{IAA}\right)$. In addition, increasing IAA concentrations may have been required to induce plants to enhance their capacity to resist high Cu-stress [34,35].

Plant cells have evolved complex antioxidant systems (enzymatic and non-enzymatic antioxidants) to cope with ROS and alleviate the deleterious effects of $\mathrm{Cu}$. Antioxidant enzymes include SOD, POD, ctalase (CAT), APX, and GR [36], and non-enzymatic antioxidants are a variety of compounds, such as proline, glutathione, ascorbic acid, and amino acids, which regulate cellular concentrations of $\mathrm{O}_{2}^{-}$and $\mathrm{H}_{2} \mathrm{O}_{2}$, thereby ameliorating the harmful effects of ROS [37]. In the present study, the application of IAA to $\mathrm{Cu}$-stressed seedlings increased the activities of antioxidant enzymes (SOD, APX, and GR) and reduced MDA concentrations, indicating that exogenous addition of IAA could induce the synthesis of antioxidant enzymes, or activate specific gene-mediated antioxidant enzyme activities [38], and, in turn, enhanced the antioxidant defense ability and reduced the lipid peroxidation damage in the seedlings [39]. Such defense capacity was more obvious, particularly at the highest IAA concentrations (60 $\mathrm{mg} \mathrm{L}^{-1}$ ). Indeed, as non-enzymatic antioxidant, the proline contents of IAA-treated seedlings were remarkably higher, which suggested that IAA application stimulated proline accumulation [40], and alleviated free-radical damage induced by $\mathrm{Cu}$ stress [8]. Therefore, the findings suggest that exogenous application of IAA improved $\mathrm{Cu}$ tolerance in seedlings by enhancing antioxidant defense systems and alleviating the damage caused by $\mathrm{Cu}$ stress.

Excessive $\mathrm{Cu}$ has been reported to interfere with $\mathrm{N}$ acquisition, assimilation, and the activities of $\mathrm{N}$-metabolizing enzymes [41,42]. The reduction of $\mathrm{NO}_{3}{ }^{-}$to $\mathrm{NH}_{4}{ }^{+}$involves $\mathrm{NR}$ and NiR, while $\mathrm{NH}_{4}{ }^{+}$ assimilation usually involves the GS-GOGAT cycle or the GDH alternative pathway [43,44]. In the present study, the total $\mathrm{N}$ and $\mathrm{NO}_{3}{ }^{-}$concentrations were reduced by $\mathrm{Cu}$ exposure (C2 treatment), and the activities of NR and NiR were also reduced, potentially due to the inhibition of inorganic $\mathrm{N}$ absorption by the $\mathrm{Cu}$ stressed seedlings [41], and the reduction capacity of $\mathrm{NO}_{3}{ }^{-}$declined with decrease in $\mathrm{Cu}$ stress $[45,46]$. However, $\mathrm{NH}_{4}{ }^{+}$content under $\mathrm{Cu}$ stress was observed to increase, compared with the $\mathrm{C} 1$ treatment, potentially because (i) the $\mathrm{N}$ metabolism of seedlings was vulnerable to $\mathrm{Cu}$ stress, which induced the accumulation of dangerously high levels of $\mathrm{NH}_{4}^{+}$[47] (ii) $\mathrm{NH}_{4}^{+}$continuously formed during various metabolic processes, such as direct absorption, photorespiration, soluble organic $\mathrm{N}$ catabolism and $\mathrm{N}$ compounds storage [48]. The present study also revealed reductions in GS and GOGAT activities, which indicated that the GS/GOGAT cycle was inhibited, thereby disrupting $\mathrm{NH}_{4}^{+}$ assimilation, and causing the observed increases in $\mathrm{NH}_{4}{ }^{+}$concentrations [39,49]. Notably, $\mathrm{NH}_{4}{ }^{+}$can also be rapidly assimilated into organic $\mathrm{N}$ through the GDH alternative pathway [50]. However, in the present study, even though GDH activity was enhanced in the $\mathrm{C} 2$ treatment, the $\mathrm{NH}_{4}{ }^{+}$concentrations remained relatively high, potentially because the GDH pathway was limited in its capacity to assimilate $\mathrm{NH}_{4}{ }^{+}$and only assimilated a small amount of $\mathrm{NH}_{4}{ }^{+}$[45]. Indeed, $\mathrm{Cd}$ toxicity has also been reported to inhibit the GS/GOGAT cycle, increase GDH activity, and increase $\mathrm{NH}_{4}{ }^{+}$concentrations in the leaves of Solanum nigrum L. [45]. In the present study, the accumulation of $\mathrm{NH}_{4}{ }^{+}$was also accompanied by a remarkable reduction in free amino acid and soluble protein contents, which indicated that the $\mathrm{Cu}$ stress inhibited $\mathrm{N}$ assimilation of seedlings and reduced the biosynthesis of free amino acids and soluble proteins $[45,51]$.

Furthermore, the exogenous application of IAA can improve plant tolerance and, in particular, can counteract the negative effects of heavy metals on plant growth [9]. However, it is unclear how 
IAA application affects $\mathrm{N}$ metabolism. Therefore, one of the aims of the present study was to measure the effects of IAA on $\mathrm{N}$ assimilation metabolism. Exogenous IAA application increased the contents of total $\mathrm{N}$ and $\mathrm{NO}_{3}{ }^{-}$, and the activities of $\mathrm{NR}$ and $\mathrm{NiR}$, which were involved in $\mathrm{NO}_{3}{ }^{-}$reduction and $\mathrm{N}$ metabolism [11,52], thereby indicating that IAA application could enhance the $\mathrm{NO}_{3}{ }^{-}$absorption efficiency of $\mathrm{Cu}$-stress seedlings, improve the activities of $\mathrm{NR}$ and $\mathrm{NiR}$, and enhance the $\mathrm{N}$ reduction capacity [11]. Similar results have been reported by previous studies. For example, the addition of $10 \mu \mathrm{mol} \mathrm{L}{ }^{-1}$ IAA to $\mathrm{Cr}$ stressed pea seedlings increased the total $\mathrm{N}$ contents of roots and shoots [11]. Moreover, the synchronous increases observed in $\mathrm{NO}_{3}{ }^{-}$content and $\mathrm{NR}$ activity in spinach seedlings could be due to the compartmentalization of $\mathrm{NO}_{3}{ }^{-}$assimilation in leaves [53], since $\mathrm{NO}_{3}{ }^{-}$is mainly stored in vacuoles [54], and isolated from NR, which is located in the cytoplasm [55].

The avoidance of excess $\mathrm{NH}_{4}{ }^{+}$accumulation is generally viewed as an important strategy for withstanding stress damage in plants [56]. In the present study, the application of IAA treatment increased the GS and GOGAT activities of $\mathrm{Cu}$-stressed seedlings, but reduced $\mathrm{NH}_{4}{ }^{+}$content, which implied that the GS-GOGAT enzyme system plays an essential role in $\mathrm{NH}_{4}{ }^{+}$detoxification [56,57]. Under stressful conditions, $\mathrm{NH}_{4}{ }^{+}$is assimilated through an alternative pathway that involves GDH [45]. In the present study, the GDH activities of the $\mathrm{Cu}$-stressed plants were elevated by IAA application, which indicated that increases in GDH activity may alleviate the adverse effects of accumulating toxic amounts of $\mathrm{NH}_{4}{ }^{+}$and may supply glutamate for the biosynthesis of protective compounds [58]. In addition, according to the results of the present study, free amino-acid and soluble protein contents increased with an increase in IAA concentrations, which may be due to IAA-induced increase in the activities of $\mathrm{N}$-metabolizing enzymes and in the efficiency of $\mathrm{N}$ assimilation [59], or due to the mitigating effects of exogenous IAA on $\mathrm{Cu}$ stress, as reported by Agami [8].

\section{Conclusions}

The present study demonstrated that the application of lower concentrations of IAA (10-40 mg L $\left.{ }^{-1}\right)$ could increase the $\mathrm{Cu}$ concentrations in $\mathrm{Cu}$-stressed seedling roots and reduce the $\mathrm{Cu}$ concentrations of $\mathrm{Cu}$-stressed seedling leaves, while higher concentrations of IAA $\left(50 \mathrm{mg} \mathrm{L}^{-1}\right)$ could notably reduce the $\mathrm{Cu}$ concentration in both roots and leaves. Together, the findings indicate that exogenous IAA application can be used to reduce $\mathrm{Cu}$ accumulation, alleviate $\mathrm{Cu}$ toxicity, and enhance $\mathrm{Cu}$ tolerance in spinach seedlings and that such benefits are the results of the enhancement of antioxidant defense systems, reducing lipid peroxidation damage, and improving the efficiency of $\mathrm{N}$ metabolism. This demonstrates that exogenous IAA application can be an alternative strategy for reducing $\mathrm{Cu}$ accumulation in vegetable crops and for remediating Cu-contaminated soil, reducing the hazardous effects of heavy metal contamination on human health and the environment.

Author Contributions: Q.G., L.W. and T.D. conducted the experiments, collected and analyzed the samples, and drafted the manuscript. Q.K. and D.N. analyzed the data and revised the manuscript. Z.L. and Q.G. conceived and designed this work. All authors have read and agreed to the published version of the manuscript.

Funding: This work was funded by Grants from the key projects of Hubei Natural Fund (innovation group) in China (2016CFA016), and the research project of Xinjiang Agricultural Vocational and Technical College (XJNZYKJ201901).

Acknowledgments: This work was funded by Grants from the key projects of Hubei Natural Fund (innovation group) in China (2016CFA016). We would like to thank Editage www.editage.cn for English language editing.

Conflicts of Interest: The authors declare no conflict of interest.

\section{References}

1. He, Z.; Shentu, J.; Yang, X.; Baligar, V.C.; Zhang, T.; Stoffella, P.J. Heavy metal contamination of soils: Sources, indicators and assessment. J. Environ. Indic. 2015, 3, 109-112.

2. Saez, C.A.; Roncarati, F.; Moenne, A.; Moody, A.J.; Brown, M.T. Copper-induced intra-specific oxidative damage and antioxidant responses in strains of the brown alga Ectocarpus siliculosus with different pollution histories. Aquat. Toxicol. 2015, 159, 81-89. [CrossRef] [PubMed] 
3. Ravet, K.; Pilon, M. Copper and iron homeostasis in plants: The challenges of oxidative stress. Antioxid. Redox Signal. 2013, 19, 919-932. [CrossRef]

4. Yoon, J.; Cao, X.; Zhou, Q.; Ma, L.Q. Accumulation of $\mathrm{Pb}, \mathrm{Cu}$, and $\mathrm{Zn}$ in native plants growing on a contaminated Florida site. Sci. Total Environ. 2006, 368, 456-464. [CrossRef] [PubMed]

5. Brun, L.; Maillet, J.; Hinsinger, P.; Pepin, M. Evaluation of copper availability to plants in copper-contaminated vineyard soils. Environ. Pollut. 2001, 111, 293-302. [CrossRef]

6. Nielsen, H.D.; Brownlee, C.; Coelho, S.M.; Brown, M. Inter-population differences in inherited copper tolerance involve photosynthetic adaptation and exclusion mechanisms in Fucus serratus. New Phytol. 2003, 160, 157-165. [CrossRef]

7. Massoud, M.B.; Sakouhi, L.; Karmous, I.; Zhu, Y.; Ferjani, E.E.; Sheehan, D.; Chaoui, A. Protective role of exogenous phytohormones on redox status in pea seedlings under copper stress. Plant Physiol. Biochem. 2016, 109, 72-83. [CrossRef]

8. Agami, R.A. Pre-soaking in indole-3-acetic acid or spermidine enhances copper tolerance in wheat seedlings. S. Afr. J. Bot. 2016, 104, 167-174. [CrossRef]

9. Gangwar, S.; Singh, V.P.; Prasad, S.M.; Maurya, J.N. Differential responses of pea seedlings to indole acetic acid under manganese toxicity. Acta Physiol. Plant. 2010, 33, 451-625. [CrossRef]

10. Ouzounidou, G.; Ilias, I. Hormone-induced protection of sunflower photosynthetic apparatus against copper toxicity. Biol. Plant. 2005, 49, 223-226. [CrossRef]

11. Gangwar, S.; Singh, V.P. Indole acetic acid differently changes growth and nitrogen metabolism in Pisum sativum L. seedlings under chromium (VI) phytotoxicity: Implication of oxidative stress. Sci. Hortic. 2011, 129, 321-328. [CrossRef]

12. Singh, M.; Singh, V.P.; Prasad, S.M. Responses of photosynthesis, nitrogen and proline metabolism to salinity stress in Solanum lycopersicum under different levels of nitrogen supplementation. Plant Physiol. Biochem. 2016, 109, 72-78. [CrossRef] [PubMed]

13. Gajewska, E.; Sklodowska, M. Nickel-induced changes in nitrogen metabolism in wheat shoots. Plant Physiol. 2009, 166, 1034-1044. [CrossRef] [PubMed]

14. Lisiewska, Z.; Kmiecik, W.; Gębczyński, P.; Sobczyńska, L. Amino acid profile of raw and as-eaten products of spinach (Spinacia oleracea L.). Food Chem. 2011, 126, 460-465. [CrossRef]

15. Becker, C.; Klaering, H.P.; Kroh, L.W.; Krumbein, A. Cool-cultivated red leaf lettuce accumulates cyanidin-3-O-(6"-O-malonyl)-glucoside and caffeoylmalic acid. Food Chem. 2014, 146, 404-411. [CrossRef]

16. Naz, S.; Anjum, M.A.; Akhtar, S. Monitoring of Growth, Yield, Biomass and Heavy Metals Accumulation in Spinach Grown under Different Irrigation Sources. Int. J. Agric. Biol. 2016, 18, 689-697. [CrossRef]

17. Gong, Q.; Wang, L.; Dai, T.; Zhou, J.; Kang, Q.; Chen, H.; Li, Z.H. Effects of copper on the growth, antioxidant enzymes and photosynthesis of spinach seedlings. Ecotoxicol. Environ. Saf. 2019, 171, 771-780. [CrossRef]

18. Naz, A.; Khan, S.; Qasim, M.; Khalid, S.; Muhammad, S.; Tariq, M. Metals toxicity and its bioaccumulation in purslane seedlings grown in controlled environment. Nat. Sci. 2013, 5, 573-579. [CrossRef]

19. Zhu, X.F.; Jiang, T.; Wang, Z.W.; Lei, G.J.; Shi, Y.Z.; Li, G.X.; Zheng, S.J. Gibberellic acid alleviates cadmium toxicity by reducing nitric oxide accumulation and expression of IRT1 in Arabidopsis thaliana. J. Hazard. Mater. 2012, 239-240, 302-307. [CrossRef]

20. Tewari, R.K.; Kumar, P.; Sharma, P.N.; Bisht, S.S. Modulation of oxidative stress responsive enzymes by excess cobalt. Plant Sci. 2002, 162, 381-388. [CrossRef]

21. Beauchamp, C.; Fridovich, I. Superoxide dismutase: Improved assays and an assay applicable to acrylamide gels. Anal. Biochem. 1971, 44, 276-287. [CrossRef]

22. Batish, D.R.; Singh, H.P.; Setia, N.; Kaur, S.; Kohli, R.K. Effect of 2-benzoxazolinone (BOA) on seedling growth and associated biochemical changes in mung bean (Phaseolus aureus). Z. Naturforsch. C J. Biosci. 2006, 61, 709-714. [CrossRef] [PubMed]

23. Nakano, Y.; Asada, K. Hydrogen Peroxide is Scavenged by Ascorbate-specific Peroxidase in Spinach Chloroplasts. Plant Cell Physiol. 1981, 22, 867-880.

24. Asgher, M.; Khan, N.A.; Khan, M.I.; Fatma, M.; Masood, A. Ethylene production is associated with alleviation of cadmium-induced oxidative stress by sulfur in mustard types differing in ethylene sensitivity. Ecotoxicol. Environ. Saf. 2014, 106, 54-61. [CrossRef] [PubMed] 
25. Bremner, J.; Mulvaney, C. Nitrogen-total. In Methods of Soil Analysis, Part 2 Chemical and Microbiological Properties, 2nd ed.; Page, A.L., Miller, R.H., Keeney, D.R., Eds.; Soil Science Society of America, Inc.; American Society of Agronomy, Inc.: Madison, WI, USA, 1982; pp. 595-624.

26. Xiong, Z.T.; Liu, C.; Geng, B. Phytotoxic effects of copper on nitrogen metabolism and plant growth in Brassica pekinensis Rupr. Ecotoxicol. Environ. Saf. 2006, 64, 273-280. [CrossRef] [PubMed]

27. Bradford, M.M. A rapid and sensitive method for the quantitation of microgram quantities of protein utilizing the principle of protein-dye binding. Anal. Biochem. 1976, 72, 248-254. [CrossRef]

28. Egamberdieva, D. Alleviation of salt stress by plant growth regulators and IAA producing bacteria in wheat. Acta Physiol. Plant. 2009, 31, 861-864. [CrossRef]

29. Singh, K.; Pandey, S.N. Effect of nickel-stresses on uptake, pigments and antioxidative responses of water lettuce, Pistia stratiotes L. Environ. Biol. 2011, 32, 391-394.

30. Yadav, P.; Kaur, R.; Kanwar, M.K.; Sharma, A.; Verma, V.; Sirhindi, G.; Bhardwaj, R. Castasterone confers copper stress tolerance by regulating antioxidant enzyme responses, antioxidants, and amino acid balance in B. juncea seedlings. Ecotoxicol. Environ. Saf. 2018, 147, 725-734. [CrossRef]

31. Chaudhry, N.Y.; Rasheed, S. Study of the external and internal morphology of Pisum sativum L., with growth hormones ie, indole-3-acetic acid and kinetin and heavy metal ie, lead nitrate. Pak. Biol. Sci. 2003, 6, 407-412.

32. Ali, B.; Rani, I.; Hayat, S.; Ahmad, A. Effect of 4-Cl-indole acetic acid on seed germination of Cicer arietinum exposed to cadmium. Acta Bot. Croat. 2007, 66, 57-65.

33. Wang, H.; Shan, X.; Wen, B.; Owens, G.; Fang, J.; Zhang, S. Effect of indole-3-acetic acid on lead accumulation in maize (Zea mays L.) seedlings and the relevant antioxidant response. Environ. Exp. Bot. 2007, 61, 246-253. [CrossRef]

34. Fassler, E.; Evangelou, M.W.; Robinson, B.H.; Schulin, R. Effects of indole-3-acetic acid (IAA) on sunflower growth and heavy metal uptake in combination with ethylene diamine disuccinic acid (EDDS). Chemosphere 2010, 80, 901-907. [CrossRef] [PubMed]

35. Albacete, A.; Ghanem, M.E.; Martinez-Andujar, C.; Acosta, M.; Sanchez-Bravo, J.; Martinez, V.; Lutts, S.; Dodd, I.C.; Perez-Alforcea, F. Hormonal changes in relation to biomass partitioning and shoot growth impairment in salinized tomato ( Solanum lycopersicum L.) plants. J. Exp. Bot. 2008, 59, 4119-4131. [CrossRef]

36. Rucinska-Sobkowiak, R.; Pukacki, P.M. Antioxidative defense system in lupin roots exposed to increasing concentrations of lead. Acta Physiol. Plant. 2006, 28, 357-364. [CrossRef]

37. Upadhyay, R.; Panda, S.K. Zinc reduces copper toxicity induced oxidative stress by promoting antioxidant defense in freshly grown aquatic duckweed Spirodela polyrhiza L. J. Hazard. Mater. 2010, 175, 1081-1084. [CrossRef]

38. Bajguz, A. Effect of brassinosteroids on nucleic acid and protein content in cultured cell of Chlorella vulgaris. Plant Physiol. Biochem. 2000, 38, 209-215. [CrossRef]

39. Ben Massoud, M.; Karmous, I.; El Ferjani, E.; Chaoui, A. Alleviation of copper toxicity in germinating pea seeds by IAA, GA3, Ca and citric acid. J. Plant Interact. 2017, 13, 21-29. [CrossRef]

40. Choudharya, S.P.; Bhardwajb, R.; Guptac, B.D.; Duttc, P.; Guptac, R.K.; Biondid, S.; Kanwarb, M. Epibrassinolide induces changes in indole-3-acetic acid, abscisic acid and polyamine concentrations and enhances antioxidant potential of radish seedlings under copper stress. Physiol. Plant. 2010, 140, 280-296. [CrossRef]

41. Llorens, N.; Arola, L.; Bladé, C.; Mas, A. Effects of copper exposure upon nitrogen metabolism in tissue cultured Vitis vinifera. Plant Sci. 2000, 160, 159-163. [CrossRef]

42. Hippler, F.W.R.; Mattos, D.J.; Boaretto, R.M.; Williams, L.E. Copper excess reduces nitrate uptake by Arabidopsis roots with specific effects on gene expression. J. Plant Physiol. 2018, 228, 158-165. [CrossRef] [PubMed]

43. Ogawa, K.; Soutome, R.; Hiroyama, K.; Hagio, T.; Ida, S.; Nakagawa, H. Co-regulation of nitrate reductase and nitrite reductase in cultured spinach cells. Plant Physiol. 2000, 157, 299-306. [CrossRef]

44. Masclaux-Daubresse, C.; Reisdorf-Cren, M.; Pageau, K.; Lelandais, M.; Grandjean, O.; Kronenberger, J.; Valadier, M.H.; Feraud, M.; Jouglet, T.; Suzuki, A. Glutamine synthetase-glutamate synthase pathway and glutamate dehydrogenase play distinct roles in the sink-source nitrogen cycle in tobacco. Plant Physiol. 2006, 140, 444-456. [CrossRef] [PubMed]

45. Wang, L.; Zhou, Q.; Ding, L.; Sun, Y. Effect of cadmium toxicity on nitrogen metabolism in leaves of Solanum nigrum L. as a newly found cadmium hyperaccumulator. J. Hazard. Mater. 2008, 154, 818-825. [CrossRef] 
46. Ashraf, M.; Foolad, M. Roles of glycine betaine and proline in improving plant abiotic stress resistance. Environ. Exp. Bot. 2007, 59, 206-216. [CrossRef]

47. Sánchez, E.; Rivero, R.M.; Ruiz, J.M.; Romero, L. Changes in biomass, enzymatic activity and protein concentration in roots and leaves of green bean plants (Phaseolus vulgaris L. cv. Strike) under high $\mathrm{NH}_{4} \mathrm{NO}_{3}$ application rates. Sci. Hortic. 2004, 99, 237-248. [CrossRef]

48. Feng, J.; Volk, R.J.; Jackson, W.A. Source and magnitude of ammonium generation in maize roots. Plant Physiol. 1998, 118, 835-841. [CrossRef]

49. Gouia, H.; Suzuki, A.; Brulfert, J.; Ghorbal, M.H. Effects of cadmium on the co-ordination of nitrogen and carbon metabolism in bean seedlings. J. Plant Physiol. 2003, 160, 367-376. [CrossRef]

50. Miflin, B.J.; Habash, D.Z. The role of glutamine synthetase and glutamate dehydrogenase in nitrogen assimilation and possibilities for improvement in the nitrogen utilization of crops. Jexpbot 2002, 53, 979-982. [CrossRef]

51. Wang, X.; Shi, G.; Xu, Q.; Hu, J. Exogenous polyamines enhance copper tolerance of Nymphoides peltatum. J. Plant Physiol. 2007, 164, 1062-1070. [CrossRef]

52. Campbell, W.H. Nitrate reductase structure, function and regulation: Bridging the gap between biochemistry and physiology. Annu. Rev. Plant Biol. 1999, 50, 277-303. [CrossRef] [PubMed]

53. Sechley, K.; Yamaya, T.; Oaks, A. Compartmentation of nitrogen assimilation in higher plants. Int. Rev. Cytol. 1992, 134, 85-163.

54. Martinoia, E.; Maeshima, M.; Neuhaus, H.E. Vacuolar transporters and their essential role in plant metabolism. J. Exp. Bot. 2006, 58, 83-102. [CrossRef] [PubMed]

55. Zhong, C.; Cao, X.; Bai, Z.; Zhang, J.; Zhu, L.; Huang, J.; Jin, Q. Nitrogen metabolism correlates with the acclimation of photosynthesis to short-term water stress in rice (Oryza sativa L.). Plant Physiol. Biochem. 2018, 125, 52-62. [CrossRef]

56. Hoai, N.T.T.; Shim, I.S.; Kobayashi, K.; Kenji, U. Accumulation of some nitrogen compounds in response to salt stress and their relationships with salt tolerance in rice (Oryza sativa L.) seedlings. Plant Growth Regul. 2003, 41, 159-164. [CrossRef]

57. Zhong, C.; Bai, Z.G.; Zhu, L.F.; Zhang, J.H.; Zhu, C.Q.; Huang, J.L.; Jin, Q.Y.; Cao, X.C. Nitrogen-mediated alleviation of photosynthetic inhibition under moderate water deficit stress in rice (Oryza sativa L.). Environ. Exp. Bot. 2019, 157, 269-282. [CrossRef]

58. Skopelitis, D.S.; Paranychianakis, N.V.; Paschalidis, K.A. Abiotic stress generates ROS that signal expression of anionic glutamate dehydrogenases to form glutamate for proline synthesis in tobacco and grapevine. Plant Cell 2006, 18, 2767-2781. [CrossRef]

59. Ibraheem, I. Physiological Effects of Some Uriede Compounds on Cultured Phaseolus Vulgaris Seedlings In Vivo and In Vitro. Master's Thesis, Fac Sci Mans University, Mansoura, Egypt, 1999; pp. 34-36. 